Article

\title{
Effectiveness Of Dismenorhoe Senam In Reducing Dismenorhoe Events In Students In Midwife Study Program In Ubudiyah University Of Indonesia Banda Aceh
}

Raudhatun Nuzul ZA1, Rizki Swastika Renjani2

IDepartmen of Midwifery, Faculty of Health Science, Universitas Ubudiyah Indonesia, Indonesia

2 Departmen of Midwifery, Faculty of Health Science, Universitas Ubudiyah Indonesia, Indonesia

\begin{tabular}{|c|c|}
\hline SUBMISSION TRACK & A B S T R A C T \\
\hline $\begin{array}{l}\text { Recieved: } 15 \text { November } 2019 \\
\text { Final Revision: } 24 \text { November } 2019 \\
\text { Available Online: } 30 \text { Desember } 2019\end{array}$ & $\begin{array}{l}\text { Dysmenorrhea is a physical disorder in women who } \\
\text { experience menstrual disorders/stomach cramps. Exercise can } \\
\text { increase endorphin production (can increase the body's natural }\end{array}$ \\
\hline KEYWORDS & $\begin{array}{l}\text { pain), can increase serotonin levels. Gymnastics is one of the } \\
\text { relaxation techniques that can be used to reduce pain. In }\end{array}$ \\
\hline Dismenorhoe Gymnastic, Dismenorhoe & \\
\hline CORRESPONDENCE & Program at the Midwifery University, Yogyakarta University, \\
\hline $\begin{array}{l}\text { Phone: } 081269966110 \\
\text { E-mail: raudhatun@uui.ac.id }\end{array}$ & $\begin{array}{l}\text { Indonesia. This type of research is a quasi-experimental } \\
\text { design with one group pretest-posttest design. The sampling } \\
\text { technique is probability sampling, with a sample of } 20 \\
\text { respondents, a data collection tool using a Lismore gymnastic } \\
\text { observation sheet and a healing scale sheet. Statistical analysis } \\
\text { was performed with a Test (T) test. Research results obtained } \\
\text { from the analysis of sig. ( } 2 \text {-tailed) obtained } 0,000 \text { which is } \\
\text { significantly very significant or very positive which is higher } \\
\text { than } \alpha=0.05 \text {. If it is acceptable, it must be accepted, done } \\
\text { before and after dysmenorrhoea exercises. It was concluded as } \\
\text { the effectiveness of gymnastic dysmenorrhea on the reduction } \\
\text { of menstrual pain in a female midwifery study program at the } \\
\text { Ubudiyah University of Indonesia. Freed so that the help of } \\
\text { gymnastic therapy is used as an alternative intervention to } \\
\text { reduce menstrual pain. }\end{array}$ \\
\hline
\end{tabular}

\section{INTRODUCTION}

According to WHO (2012), an incidence of 1,769,425 (90\%) women experienced dysmenorrhea with 10-15\% experiencing severe dysmenorrhea. In Indonesia, more women 
who experience dysmenorrhea do not report or visit a doctor. It is said that $90 \%$ of Indonesian women have experienced dysmenorrhea (Gumangsari, 2014).

In Indonesia in 2009 (in Proverawati, 2013) the incidence of dysmenorrhea consisted of $72.89 \%$. The prevalence of dysmenorrhea in Central Java in 2012 was $0.20 \%$ lower than in $2011(0.25 \%)$. Primary dysmenorrhea $27.11 \%$ and secondary dysmenorrhea $25.20 \%$ and the incidence of dysmenorrhea ranges from $45-95 \%$ among women of childbearing age.

The incidence of menstrual pain in the world is very large. On average more than $50 \%$ of women in each country experience menstrual pain. The percentage in the United States is around $60 \%$ and in Sweden around $72 \%$. While in Indonesia the figure is estimated at $55 \%$ of women of childbearing age who are tortured by pain during menstruation. The incidence (prevalence) of menstrual pain ranges from 45 - 95\% among women of childbearing age.

Dysmenorrhea is pain during menstruation every month that can interfere with the activities of daily activities that can reduce the time to rest and leave work. Almost all women experience discomfort in the lower abdomen during menstruation. The uterus or uterus consists of muscles that also contract and relax. Generally, uterine muscle contractions are not felt but the contractions are severe and often cause disruption of blood flow to the uterus causing pain (Aulia, 2009)

Dysmenorrhea Non-pharmacological therapies include warm compresses, exercise, Mozart therapy, and relaxation. Exercise can increase endorphin production (the body's natural pain killer), can increase serotonin levels. Besides safer prevention by doing gymnastics or commonly called gymnastics dysmenorrhea. Light exercise is highly recommended to reduce dysmenorrhea. This exercise can stimulate the endorphin hormone which functions as a natural sedative and causes a sense of comfort (Harry, 2005)

Gymnastics is one of the relaxation techniques that can be used to reduce pain. This is caused when doing gymnastics the body will produce endorphins. Endorphin is a neuropeptide produced by the body when it is relaxed/calm. Endorphin is produced in the brain and spinal cord structure.

This hormone can function as a natural sedative which produces the brain that gives birth to a sense of comfort and reduce pain during contraception. So that exercise will be effective in reducing pain problems, especially dysmenorrhea (Achmad Suparto, 2011)

The specific objective in this study was to determine the effectiveness of dysmenorrhoeic exercise on the decline in dysmenorrhoea after treatment given to midwifery students at the Indonesian Ubudiyah University.

Dysmenorrhea is a physiological process that is passed by every woman, but this can be passed by handling non-pharmacological therapies such as gymnastics, a treatment such as exercise movements that move joint muscles in order to reduce pain during menstruation. In this study, the treatment will be carried out to obtain the results of the effectiveness of dysmenorrhea on the reduction of dysmenorrhea.

\section{II.METHODS}

\section{a. Research Design and Design}

The design in this study used quasi-experimental techniques (quasi-experimental) with the pretest-posttest control group design.

The population in this study were all active midwifery students of D-III and D-IV Midwifery courses at the University of Ubudiyah Indonesia from level 1 to level 3. The sampling technique uses purposive sampling, which is sampling that has fulfilled the requirements or criteria set by researchers. The total research subjects needed in this study were 30 research subjects. 
This research was conducted at the Ubudiyah University of Indonesia Campus with 30 respondents from D-III and D-IV Midwifery Study Program students on 25 May - 02 September 2019. Respondents were first explained about the benefits of doing dysmenorrhoea gymnastic movements and then given time to make these movements by being guided by an enumerator or researcher. Pain scale assessment uses a numerical rating scale, namely: value 0 no pain experienced, value 1-3 mild pain, value 4-6 moderate pain, value 7-9 severe pain, and value 10 very severe pain.

\section{RESULT}

\section{Table 1 Characteristics of Respondents}

\begin{tabular}{ccccc}
\hline No & & Characteristics & F & \% \\
\hline $\mathbf{1}$ & Age & & & \\
& Early Teans & $(12-16)$ & 0 & 0.0 \\
& Late Teens & $(17-25)$ & 30 & 100.0 \\
& & Total & 30 & 100.0 \\
$\mathbf{2}$ & Menarche & & & \\
& & 12 years old & 14 & 46.7 \\
& & 13 years old & 7 & 23.3 \\
& & 14 years old & 9 & 30.0 \\
& & Total & $\mathbf{3 0}$ & $\mathbf{1 0 0 . 0}$ \\
\hline
\end{tabular}

Based on table 1 it can be seen that all respondents were in the final adolescent category of 30 respondents (100\%) who experienced dysmenorrhoea. While the students who experienced menarche were at the age of 12 years as many as 14 respondents $(46.7 \%)$ at the time of menstruation experienced menstrual pain. Each respondent who experienced pain during menstruation varied from mild and severe.

Table 2 Distribution of Pain Scale Before Intervention in Midwifery Students at Ubudiyah University of Indonesia

Derajat Dismenorhoe
Nyeri Sedang
Nyeri Berat
Nyeri Sangat Berat
Total

Frekuensi
7
22
1
30

Persentase
23.3
73.3
3.3
$\mathbf{1 0 0 . 0}$

Based on data from table 2 above it can be seen that of the 30 respondents $(73.3 \%)$ experiencing more severe dysmenorrhoea compared to respondents who experienced moderate dysmenorrhoea $(23.3 \%)$ and respondents who experienced severe dysmenorrhoea, namely as many as 1 respondents $(3.3 \%)$.

\section{Bivariate Analysis (T-Test)}

Table 3 Test Results of Dysmenorrhea Gymnastics Analysis of Decreased Dysmenorrhea in Midwifery Students at the University of Ubudiyah Indonesia

\begin{tabular}{llcccc}
\hline \hline & Group & N & Mean & Std. Deviation & Sig. (2-tailed) \\
\hline \hline Dysmenorrhoea & Before & 30 & 7.20 & 1.186 & \\
Gymnastics & After & 30 & 3.67 & 0.884 & .000 \\
\hline \hline
\end{tabular}


The results of the statistical analysis above show that the average results before dysmenorrhoea exercises were performed on female students who experienced menstrual pain which was 7.20 with a standard deviation before doing gymnastics 1,186 and after gymnastics which was 3.67 with a standard deviation of 0.884 . the results of the analysis are in sig. (2-tailed) obtained 0,000 which means infinity or very meaningful whose value is smaller than $\alpha=0.05$. So it can be concluded that Ha was accepted, there were significant differences before and after the dysmenorrhoea gymnastics were performed in the midwifery study program at the University of ubudiyah Indonesia.

\section{DISCUSSION}

Based on table 1 it can be seen that all respondents were in the final adolescent category of 30 respondents $(100 \%)$ who experienced dysmenorrhoea. While the students who experienced menarche were at the age of 12 years as many as 14 respondents $(46.7 \%)$ at the time of menstruation experienced menstrual pain. Each respondent who experienced pain during menstruation varied from mild and severe.

This is in line with the results of the study (Rosanti, 2017) in grade VIII students of SMP Negeri 1 Ungaran with the results that there is a relationship between the age of menarche and dysmenorrhea $(\mathrm{p}=0.029)$. At the age of menarche $11-16$ years as many as $65.6 \%$ and those experiencing dysmenorrhea as much as $56.3 \%$. This is because of the different nutrients in adolescents. A child with good nutrition, the age of menarche will be fast and menopause will be slower, causing pain during menstruation. And conversely, if someone has an unhealthy lifestyle (smoking or never exercise) then the pain during menstruation will increase.

This is in line with the statement (Trihono, 2010) which states that in Indonesia the age of menarche occurs on average at the age of 13 years, and is said to be normal if it occurs at the age of 12 years. The age of early menarche or usually $<12$ years causes problems in adolescents and unpreparedness due to maturation of the reproductive organs which then results in dysmenorrhea, dysmenorrhea events due to not reaching the biological maturity of Wulandari \& Ungsianik, 2013).

The results of a study conducted by Nancy Monika Sormin in 2014, explained that besides that, Manuaba (2010), also stated that at the age of 13-16 years, a teenager will experience puberty that starts with the growth of primordial ovarian follicles that secrete the hormone estrogen. The removal of the hormone estrogen causes the growth of secondary sex signs such as breast enlargement, pubic hair growth, armpit hair growth, and eventually, the first menstrual blood expenditure occurs.

Based on the results of the statistical analysis in Table 3 above shows that the average results before dysmenorrhoea gymnastics performed on students who experienced pain during menstruation are 7.20 with a standard deviation before doing gymnastics 1,186 and after gymnastics is 3.67 with a standard deviation of 0.884 . the results of the analysis are in sig. (2tailed) obtained 0.000 which is very significant or very significant which value is smaller than $\alpha=0.05$. So it can be concluded that Ha was accepted, there were significant differences before and after the dysmenorrhoea gymnastics were performed at the midwifery study program at the University of ubudiyah Indonesia.

Based on the results of the research conducted by Maria. Et al, entitled 'The Effectiveness of Dysmenorrhea Gymnastics in Reducing Dysmenorrhea in Students of Study Program D III Karawang Midwifery in 2013 "in the study explained that dysmenorrhea or menstrual pain is normal, but can be overestimated when influenced by physical and psychological factors such as stress and the influence of prostaglandin hormones and progesterone. During dysmenorrhea, uterine muscle contractions occur due to an increase in prostaglandins, causing vasospasm of uterine arterioles which causes ischemia and cramps in the lower abdomen which will stimulate 
pain during menstruation (Robert and David, 2004). Sports or gymnastics dysmenorrhea is one of the relaxation techniques. Sports or physical exercise can produce endorphin hormones. Endorphin is a neuropeptide that is produced by the body when it is relaxed/calm. Endorphins are produced in the brain and spinal cord. This hormone can function as a natural sedative produced by the brain that gives birth to a sense of comfort and increases endorphin levels in the body to reduce pain during contractions. Exercise has been shown to increase levels of bendorphin four to five times in the blood. Thus, the more gymnastics/sports the higher the bendorphin levels. When someone does sports/gymnastics, the b-endorphin will come out and be captured by the receptors in the hypothalamus and limbic system that functions to regulate emotions. Increased b-endorphin has been shown to be closely related to decreased pain, increased memory, improved appetite, sexual ability, blood pressure and breathing (Harry, 2007).

\section{CONCLUSION}

The conclusion is the effectiveness of gymnastic dysmenorrhea on the reduction of menstrual pain in a female midwifery study program at the Ubudiyah University of Indonesia. Freed so that the help of gymnastic therapy is used as an alternative intervention to reduce menstrual pain. 


\section{REFERENCES}

Bianca EA. Hubungan Antara Usia Menarche dengan Dismenorrhea Primer. Universitas Muhammadyah Surakarta. 2018.

Harry. Mekanisme Endorphin dalam Tubuh.. Available at Http:/klikharry.files.wordpress.com/2007/02/1.doc + endorphin + dalam +tubuh. 2007. Dibuka tanggal 16 Nopember 2012.

Joharmi.. Factors-Factors to The event Dysmenorhoe in Grade X in SMK Asyifa Kisaran Tahun 2015. Jurnal Ilmiah Kohesi Vol 1 No. 1 April 2017. Akademi Kebidanan As Syifa Kisaran. 2017.

Manuaba, I. A., Manuaba, I. B., \& Manuaba, I. B. Buku Ajar Penuntun Kuliah Ginekologi. Jakarta: TIM. 2010.

Manuaba, I.A.C., Manuaba, I.B.G.F., \& Manuaba, I.B.G. Ilmu Kebidanan, Penyakit Kandungan, dan KB untuk Pendidikan Bidan. Jakarta: EGC. 2010.

Maria, AR.dkk.. Efektivitas Senam Dismenore dalam Mengurangi Dismenore pada Mahasiswa Program Studi D III Kebidanan Karawwang Tahun 2013. Jurnal Ilmiah Solusi Vol. 1 No. 2 April-Juni 2014. 2014

Nancy, MS. Efektivitas Senam Dismenorhoe dalam Mengurangi Dismenorhoe pada Remaja Putri di SMP Negeri 2 Siantan Kabupaten Pontianak. Naskah Publikasi. Universitas Tanjung Pura Pontianak. 2014

Rosanti, A. Faktor-faktor yang mempengaruhi kejadian disminore pada siswi kelas VIII SMP Negeri 1 Ungaran Kabupaten Semarang tahun 2017. Universitas Ngudi Waluyo Ungaran.

Trihono. (2010). Riset Kesehatan Dasar. Badan Penelitian Dan Pengembangan Kesehatan, 78. Retrieved from https://doi.org/1 Desember 2013. 2017

Wulandari, S., \& Ungsianik, T. Status Gizi, Aktivitas Fisik, dan Usia Menarche Remaja Putri. Jurnal Keperawatan Indonesia, 16(1), 55-59. Retrieved from journal.ui.ac.id.. 2013

\section{BIOGRAPHY}

First Author : Raudhatun Nuzul ZA, S.SST., M.Kes, 2013 until now as a midwifery lecturer at the Faculty of Health Sciense at the Indonesian ubudiyah university. 2017-2018 Beginner lecturer research grants from Ristekdikti, 2018-2019 are given another chance to win a beginner lecturer research grant. 2017 once published proceedings in one international journal. 